\title{
First report of Alternaria alternata causing discoloration on Amaranthus seeds in Argentina
}

\author{
María Cristina Noelting • Marina Noemí Sisterna • \\ Gladys Lori • María Cristina Sandoval • \\ María del Cármen Molina • Cecilia Inés Mónaco
}

Received: 11 November 2010 / Accepted: 11 January 2011 /Published online: 23 March 2011

(C) Australasian Plant Pathology Society Inc. 2011

\begin{abstract}
Alternaria alternata is recorded as the causal agent of seed discoloration of Amaranthus caudatus ssp. mantegazzianus for the first time in Argentina.

Keywords Amaranth - Seeds discoloration - Mycoflora Alternaria alternata $\cdot$ Fusarium equiseti $\cdot$ Cladosporium cladosporiodes $\cdot$ Penicillium $\mathrm{sp} \cdot$ Phoma $\mathrm{sp} \cdot$ Bipolaris $\mathrm{sp}$. Rhyzopus nigricans $\cdot$ Blotter test $\cdot$ Agar test
\end{abstract}

Amaranthus caudatus ssp. mantegazzianus (amaranth) is an ancestral crop native to Bolivia and Argentina. Stems, leaves and seeds have a high nutritional value and contain proteins that act as antioxidants (Tironi and Añon 2010) and antitumorals (Barrio and Añón 2010). Among the fungal pathogens that affect amaranth, Alternaria alternata is the causal agent of spots and blights on leaves (Noelting et al. 2009).

M. C. Noelting $(\bowtie) \cdot$ M. Molina

IFSC, Llavallol pcia de Bs. As,

Buenos Aires, Argentina

e-mail: mcnoelting@hotmail.com

M. N. Sisterna • G. Lori • C. I. Mónaco

CIC CIDEFI, La Plata, Argentina

M. C. Noelting $\cdot$ M. N. Sisterna $\cdot$ G. Lori $\cdot$ M. Molina $\cdot$

C. I. Mónaco

FCAyF(UNLP), calle 60 y 119 ,

La Plata, CP 1900, Argentina

M. C. Sandoval

FCA (UNLZ), Ruta 4 Km 2 Llavallol,

Buenos Aires, Argentina

M. Molina

FCAyF(UNLP) CONICET, calle 60 y 119 ,

La Plata, CP 1900, Argentina
In April 2008, discolored seeds (Fig. 1c) from an amaranth crop (Fig. 1a), cultivated in Llavallol, Buenos Aires province, Argentina were observed. Standard sanitary methods viz blotter and agar tests (Neergaard 1979) were used to investigate the microorganisms present in these seeds and their effect on germination. Discolored and normal seeds were plated on Petri dishes and incubated for seven days at $25 \pm 2{ }^{\circ} \mathrm{C}$ in a growth chamber under $12 \mathrm{~h}$ photoperiod.

The fungus most frequently isolated from the discolored seed was Alternaria alternata with a contamination percentage of $40 \%$ (blotter test) and $42 \%$ (agar test). The other common fungi recovered were Fusarium equiseti, Penicillium sp, Bipolaris sp, Cladosporium cladosporioides, Phoma and Rhizopus nigricans.

An isolate of Alternaria alternata was plated on Petri dishes with water agar and incubated in a growth chamber $25 \pm 2^{\circ} \mathrm{C}$ under $12 \mathrm{~h}$ photoperiod. The isolate exhibited a sporulation pattern with more than three branches of conidia per chain (Fig. 2).

Conidia were ovoid to ellipsoidal with a yellowish brown colour and transverse and longitudinal septa. Mature conidia measured $24.6 \pm 3.5 \times 14.6 \pm 0.7 \mu \mathrm{m}$.Conidiophores were solitary and measured $32.4 \pm 8.9 \mu \mathrm{m}$. Colonies on PDA had a felted appearance and were dark grey with a diameter of $45 \mathrm{~mm}$ after 7 days incubation. The isolates were identified belonging to A. alternata according to their sporulation pattern (Fig. 2a) and morphology of conidia and conidiophores (Simmond 1995). The isolate of $A$ alternata has been lodged in the culture collection of the Instituto Carlos Spegazzini, Facultad de Ciencias Naturales y Museo, Universidad Nacional de La Plata, Buenos Aires, Argentina, with the accession number LPSC $\mathrm{N}^{\circ} 1085$. 
Fig. 1 (a) Panicle of Amaranthus caudatus ssp. mantegazzianus; (b) seeds with normal appearance; (c) discolored seeds
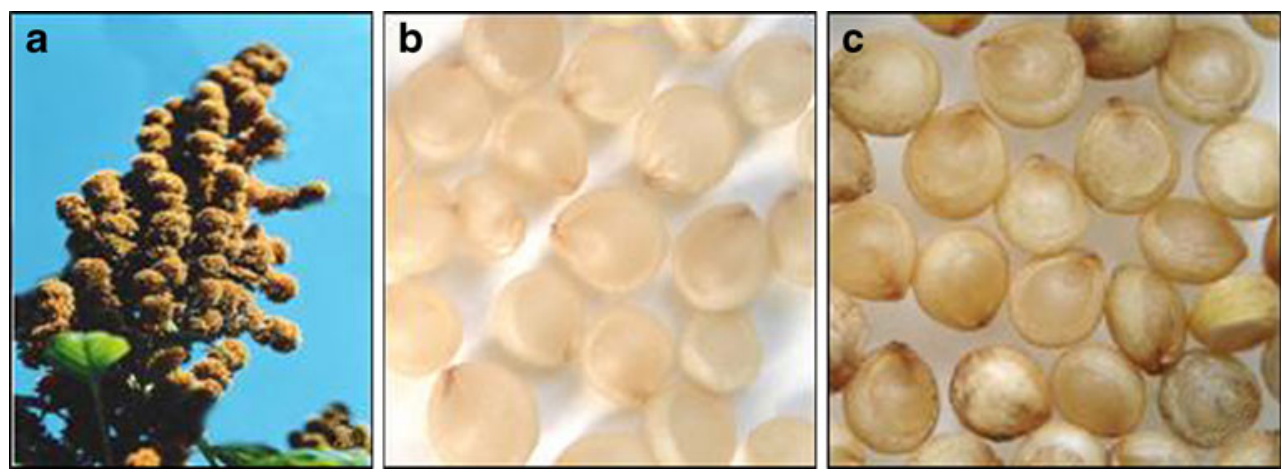

Fig. 2 (a) Sporulation pattern of Alternaria alternata; (b) healthy seed; (c) seed inoculated with A. alternata
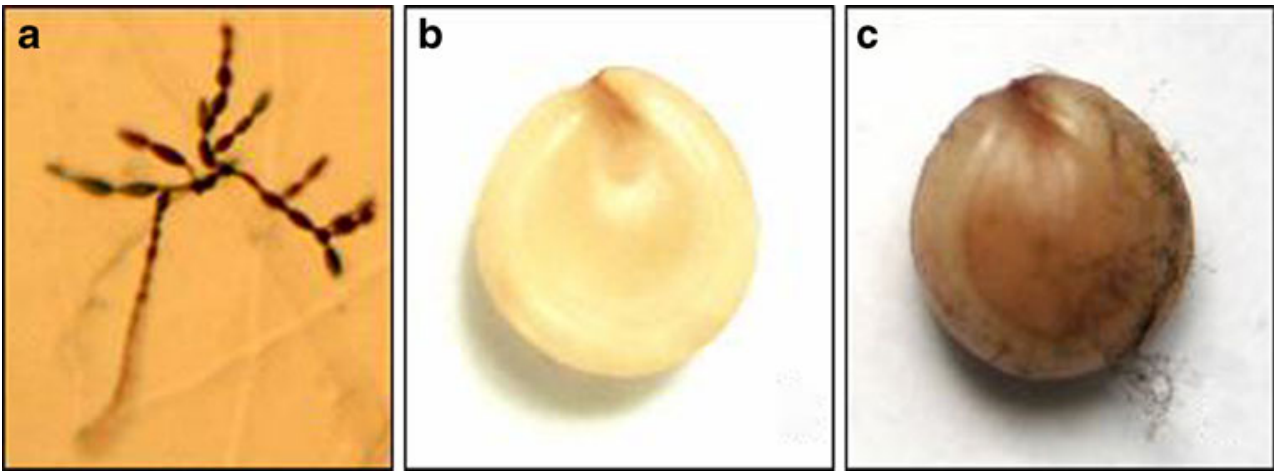

In order to determinate if $A$. alternata was the possible cause of discoloration, pathogenecity tests were carried out. Amaranth seeds with healthy appearance (Fig. 1b) were inoculated with a conidial suspension $\left(1 \times 10^{5}\right.$ conidia $\left./ \mathrm{ml}\right)$ and incubated for seven days at $25 \pm 2{ }^{\circ} \mathrm{C}$ and $10 \pm 2{ }^{\circ} \mathrm{C}$ in a growth chamber under $12 \mathrm{~h}$ photoperiod. Untreated seeds were included as a control.

Pathogenicity tests showed the ability of $A$. alternata to produce seed discoloration at both incubation temperatures (Fig. 2b-c). At $25 \pm 2{ }^{\circ} \mathrm{C}$, discoloration integuments of germinated and ungerminated seeds were observed. A significant reduction in seed germination and an increase in the number of abnormal plants was also seen.

A. alternata was re-isolated from the seeds confirming Koch's Postulates and the pathogenicity of the fungus. Germination values were $37 \%$ for discolored seeds and $85 \%$ for seeds of normal appearance. No disease symptoms were observed in the controls (Fig. 1b).

This pathogen was also detected on discoloured amaranth seeds from La Pampa and Cordoba Provinces, Argentina. Although there are previous records of fungi on amaranth seeds (Noelting et al. 2004, 2006), this is the first report of $A$. alternata as the cause of discolored seeds on this crop in Argentina. Further studies are needed to determine if this pathology affects the nutritional quality of the seeds.

\section{References}

Barrio DA, Añón MC (2010) Potential antitumor properties of a protein isolate obtained from the seeds of Amaranthus mantegazzianus. Eur J Nutr 49:73-82

Neergaard P (1979) Seed Pathology. Vols 1 and 2. The Macmillan Press: London 839

Noelting MC, Sandoval MC, Abbiati NN (2004) Determinación de microorganismos fúngicos en semillas de amaranto (Amaranthus L.) mediante diversos métodos de análisis. Revista Peruana de Biologia 11:169-178

Noelting MCI, Mónaco CI, Sandoval MC, Molina MC (2006) Estrategias de manejo integrado del tizón foliar (Alternaria alternata) en un cultivo de amaranto (Amaranthus spp.). XII Jornadas Fitosanitarias Argentinas, Catamarca, Argentina, 310 311.

Noelting MC, Sandoval MC, Molina MC (2009) Revisión de las principales patologías que afectan al cultivo de amaranto en Argentina. Jornadas Amaranto La Plata 2009:25

Simmond EG (1995) Alternaria themes and variations. Mycotaxon 55:55-163

Tironi VA, Añon MC (2010) Amaranth protein as a source of antioxidant peptides. Effect of proteolisis. Food Res Int 43:315322 